\title{
EVALUATING THE PERFORMANCE OF SOME LOCAL AND IMPORTED EMITTERS TO IMPROVE THEIR HYDRAULIC PERFORMANCE
}

\author{
Asmaa. A.M. Mohamed ${ }^{1 *}$, Abdel-Aziz ${ }^{1}$ A.A., Beder ${ }^{1}$, O.M.A. and Soultan ${ }^{2}$ W.M.M. \\ 1. Agric. Engineering Dept., Fac. of Agric., Ain Shams Univ., Ain Shams Univ., P.O. 68 \\ Hadayek Shobra 11241, Cairo, Egypt. \\ 2. Agricultural Research \& Drainage Research Laboratory, Agricultural Engineering Re- \\ search Institute, Dokki, Giza, Egypt
}

*Corresponding author: asmaa.1641991@gmail.com

Received 6 January, 2019, Accepted 10 February, 2019

\section{ABSTRACT}

Due to the climatic changes in Egypt, the remarkable population growth and the high demand for water, especially for irrigation water. To rationalize the use of irrigation water, it has been applied efficient irrigation systems such as trickle irrigation system for irrigating trees and plants by securing the least amount of water for the plant without wasting and saturation of the surrounding area. This study aims to evaluate the performance of some local and imported emitters. In this study, 16 emitters were used (9 imported emitters and 7 local emitters) divided into (9 non-pressure compensating and 7 pressure compensating), for evaluation under different operating pressures $(0.5$, $0.75,1,1.25$ and 1.5 bar), in addition to measure the hydraulic performance of the manufacture's coefficient of variation (CV \%), emitter flow variation $\left(\boldsymbol{q}_{\text {var }} \%\right)$, and the emission uniformity (EU \%). The results showed that the highest emission uniformity value for emitters of (OT1, OT2, KF, TKY, CKF and OT3), with discharge of (2) $\mathrm{L} / \mathrm{h}$ nonpressure compensating (NPC), $4 \mathrm{l} / \mathrm{h}$ non-pressure compensating (NPC), $4 \mathrm{I} / \mathrm{h}$ pressure compensating (PC), $8 \mathrm{l} / \mathrm{h}$ non- pressure compensating (NPC), $8 \mathrm{I} / \mathrm{h}$ pressure compensating (PC) and $16 \mathrm{I} / \mathrm{h}$ non-pressure compensating (NPC) respectively, while, the lowest manufacture's coefficient of variation value $(\mathrm{CV} \%)$, emitter flow variation $\left(\boldsymbol{q}_{\text {var }} \%\right)$ were used with 6 emitters in the second part of the laboratory experiment to evaluate the side lines under the length of the hoses $(50,75,100 \mathrm{~m})$ at a distance between the emitters ( $4 \mathrm{~m})$, for the calculation of the emission uniformity (EU\%), friction losses and consumption of power. From the last result in laboratory and through evaluation the 6 emitters under study in terms of prices and emission uniformity (EU\%), a randomized field study was conducted on the farms where the three emitters (OT2, KF and OT1) under lateral length (50 m) and emitter spacing $(4 \mathrm{~m})$. The purpose of the field test was carried out to determine the degree of clogging throughout the operating period (after 2 and 4 years). A field test used an emitter (OT1, OT2 and KF) found for two months and has been used again for two years when farming in the farm was expanded and used four years ago by expanding the farm, the emitter (OT2) clogging ratio was $3.09 \%$ within two months, $6.95 \%$ within two years and $10.49 \%$ within 4 years, the emitter (OT1) clogging ratio was $5.26 \%$ within two months, $11.11 \%$ within two years and $17.64 \%$ within 4 years, the emitter (KF) clogging ratio was $6.83 \%$ within two months, $13.63 \%$ within two years and $20.96 \%$ within 4 years. The results showed that the lowest degree of clogging ratio of the emitter (OT2) was within two months of operation. In general, and as expected, the results indicate that clogging ratio increased with increasing the time of installation of the field emitter and the range of factors affecting the periodic maintenance and design of good and components of irrigation network with high quality and ratio of manufacture's coefficient of variation (CV\%).

Keywords: Emitters type, trickle irrigation, hydraulic the manufacture's coefficient of variation, emission uniformity, friction losses. 


\section{INTRODUCTION}

There is now competition for water between agriculture, municipal supplies, the environment plans and will become more in the future, due to the increase in the population of the world impact of climate change. $70-90 \%$ of advanced water supplies are used for agriculture; it will be the first source to be used to meet competing demand for the water. It is important to remember that nearly $40 \%$ of global food supplies come from irrigated agriculture and there will be further pressure in the future to meet the growing need for food. To address the take on of water and nutrition keeping, irrigated agriculture will have to improve water productivity (Postel, 1999), trickle Irrigation is an effective irrigation method, that distributes water uniformly, controls of the quantities water used with high precision, reduces evaporation, deep percolation, and salinity effect. Therefore, irrigation of the trickle has become one of the most common and used irrigation methods. But it also has some drawbacks; for example, water distribution has been amounting reduced due to obstruction of the emitter (Ayars et al 1999). Trickle Irrigation, also called the irrigation of micro system, is a slowlocalization method that often tool up trickle irrigation mechanization. Their own been plentiful studies on hydraulics of the trickle irrigation systems. (Evans, 2000). The selection of the emitters is difficult in order to be varieties of emitter characteristics which have to be deeming in relation to the crop, the soil and the topography, and the respective choice regarding with performance of a hydraulic of the system. Water enters to emitters at approximately, 1 bar and is delivered at zero pressure in the form of continuous droplets at low rates of 1-24 l/h showed by (Phocaides, 2000). To increase irrigation efficiency, small irrigation mode such as trickle mode, require only 20 to $30 \%$ of the water when compared to traditional irrigation mode (Tagar et al 2010). variation in the rate of flow coefficient of variation of the emitter is united to the clogging process, which is major cause by the kind of the water applied in irrigation, because of the trouble does not impact every emitter evenly (Ribeiro et al 2010). Two similarity standards applied in irrigation of dripping layout is flow of the emitter Variation $\left(q_{v a r} \%\right)$ and manufacturer's coefficient of variation (CV \%), several investigators stated values of manufacturer's coefficient of variation (CV $\%)$ to the emitters after applied some time (Tripathi et al 2011). In drip irrigation system, the similarity of water enforcement from emitters depends on lateral lines length, emitters design, operating pressure, friction losses, the industrialization difference of emitter and emitter's tendency to clogging. The uniformity of water is related to the pressure variation along the lateral line. The friction losses and the lateral line inclination largely affect the pressure variation stated by (Sinobas and Rodriguez 2012). The selection of good and timely emitters is the first step for infallible trickle irrigation method design, as well as, the similarity of the water application from trickle irrigation method is reflected by both water pressure distribution in pipes network and properties of hydraulic of emitters said by (Abdel Salam 2016).

So, the main objectives of this study were evaluated the available emitters in local market, evaluated emitters laterals (lateral length and spacing between emitter), calculating uniformity coefficient, coefficient of variation and measuring friction losses, calculation of the consumption of power and evaluate the clogging emitters ratio in field.

\section{MATERIALS AND METHODS}

\section{1- Laboratory experiment}

Laboratory experiments were carried out at the National Irrigation Laboratory of Agricultural Engineering Research Institute (AEnRI), Dokki, Giza, to evaluation the 16 emitters available in the local market. By comparing the results to local and imported emitters have the same flow rate.

Apparatus was used to evaluate the emitters as shown in Fig. (1) and it consist of the following components.

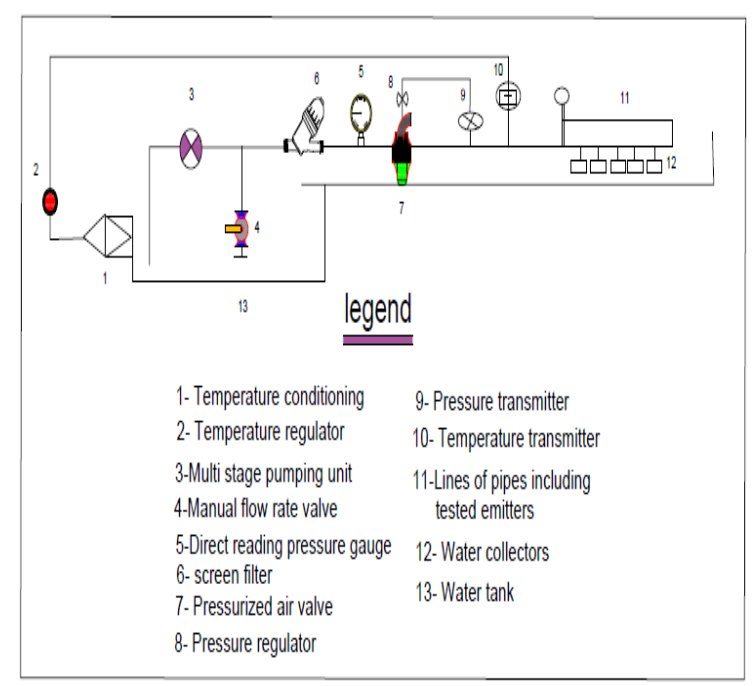

Fig. 1. Hydraulic test bench components 
a) Pump description were presented in Table (1)

Tables 1. Pump characteristics

\begin{tabular}{|c|c|}
\hline Pump type & Characteristics type \\
\hline Speed & $1450 \mathrm{rpm}-50 \mathrm{HZ}$ \\
Head & $6 \mathrm{bar}$ \\
Flow rate & $3 \mathrm{~m}^{3} / \mathrm{h}$ \\
Voltage & $(220-380 \mathrm{~V})$ \\
Power & $0.75 \mathrm{KW}$ \\
\hline
\end{tabular}

b) Water tank: it made of fiber glass, cylindrical shape with a semi spherical bottom, designed to avoid deposits accumulation, volume of water storage is $500-7001$.

c) Hoses arrangement: Five polyethylene (PE) lateral tubes of $16 \mathrm{~mm}$ (O.D) and $1.3 \mathrm{~mm}$ wall thickness and $3 \mathrm{~m}$ in length in hydraulic test bench.

d) Temperature regulation: During testes of water temperature shall remain to $23^{\circ} \mathrm{C} \pm 2^{\circ} \mathrm{C}$ (ISO
9260). The automatic regulation system shall be able to maintain the requested water temperature in the following condition: Ambient air temperature from $10 \stackrel{\circ}{ } \mathrm{C}$ up to $50 \stackrel{\circ}{\circ}$, maximum flow rate $6 \mathrm{~m}^{3} / \mathrm{h}$, continuous pumping operation during 8 hours and temperature regulation system power supply 220/380 V - $50 \mathrm{~Hz}$.

e) Filtration: A washable strainer type filter shall be positioned on the main supplying pipe after the manual flow rate valve and before the automatic pressure regulator valve. Filtration capacity $10 \mathrm{~m}^{3} / \mathrm{hr}$ and aperture size $80 \mu \mathrm{m}$ (According to ISO 1991). A non-pressurized strainer had been positioned between the returning water and the tank (aperture size $200 \mu \mathrm{m}$ ).

f) Emitters: Twenty five new emitters were selected randomly from each type were tested and mounted at $0.5 \mathrm{~m}$ spacing on lateral tested. Types of emitters and specification are shown in Table (2).

Table 2. Some types of emitters used in the present investigated

\begin{tabular}{|c|c|c|c|c|c|}
\hline \multirow{2}{*}{ No } & \multirow{2}{*}{ Emitter type } & \multirow{2}{*}{ Emitter Name } & Flow rate, $\mathrm{l} / \mathrm{h}$ & \multirow{2}{*}{ Classification } & \multirow{2}{*}{$\begin{array}{c}\text { Operating } \\
\text { pressure } \\
\text { (bar) }\end{array}$} \\
\hline & & & Nominal & & \\
\hline 1 & \multirow{3}{*}{ Imported } & OT1 & 2 & $\mathrm{NPC}^{*}$ & $0.8-2$ \\
\hline 2 & & OT2 & 4 & $\mathrm{NPC}^{*}$ & $0.8-2$ \\
\hline 3 & & OT3 & 16 & $\mathrm{NPC}^{*}$ & $0.8-2$ \\
\hline 4 & \multirow{4}{*}{ Local } & NC1 & 2 & $\mathrm{NPC}^{*}$ & $0.8-2.5$ \\
\hline 5 & & $\mathrm{NC2}$ & 4 & $\mathrm{NPC}^{*}$ & $0.8-2.5$ \\
\hline 6 & & NC3 & 8 & $\mathrm{NPC}^{*}$ & $0.8-2.5$ \\
\hline 7 & & NC4 & 16 & $\mathrm{NPC}^{*}$ & $0.8-2.5$ \\
\hline 8 & \multirow{6}{*}{ Imported } & $\mathrm{KF}$ & 3.75 & PCS & $0.8-3$ \\
\hline 9 & & $\mathrm{RD}$ & 4 & $\mathrm{pc}^{* *}$ & $0.8-3$ \\
\hline 10 & & EN & 4 & $\mathrm{pc}^{* *}$ & $0.8-3$ \\
\hline 11 & & NN & 4 & $p c^{* *}$ & $0.8-3$ \\
\hline 12 & & TKY & 8 & $\mathrm{NPC}^{*}$ & $0.5-2.5$ \\
\hline 13 & & CKF & 8 & $\mathrm{PCS}^{* * *}$ & $0.5-4$ \\
\hline 14 & \multirow{3}{*}{ Local } & MPT & 4 & $\mathrm{NPC}^{*}$ & $0.8-2$ \\
\hline 15 & & NPC1 & 4 & $\mathrm{pc}^{* *}$ & $0.8-3$ \\
\hline 16 & & NPC2 & 8 & $\mathrm{pc}^{* *}$ & $0.8-3$ \\
\hline
\end{tabular}

$p c^{* *}:$ Pressure compensating

$\mathrm{PCS}^{* * *}$ : Pressure compensating and self-flushing

$\mathrm{NPC}^{*}$ : Non-Pressure compensating

\section{Experiment description}

By comparing (16 emitters) in terms of the hydraulic performance of the manufacture's coefficient of variation (CV\%) - emitter flow variation $\left(q_{\mathrm{var}} \%\right)$ - the emission uniformity (EU\%). Evaluate the lateral lines for six types of emitters were used from (16 emitters above-mentioned in the first part was to Lab. Experiment), under the length of the hoses $(50,75,100 \mathrm{~m})$ at a distance between the 
emitters (4 m), as shown in Fig. (2), when operating pressure (1bar), for the calculation of the emission uniformity (EU \%), the coefficient of friction of the hydraulic and calculation of the consumption of power, for the calculation of the emission uniformity (EU \%), and the coefficient of friction of the hydraulic.

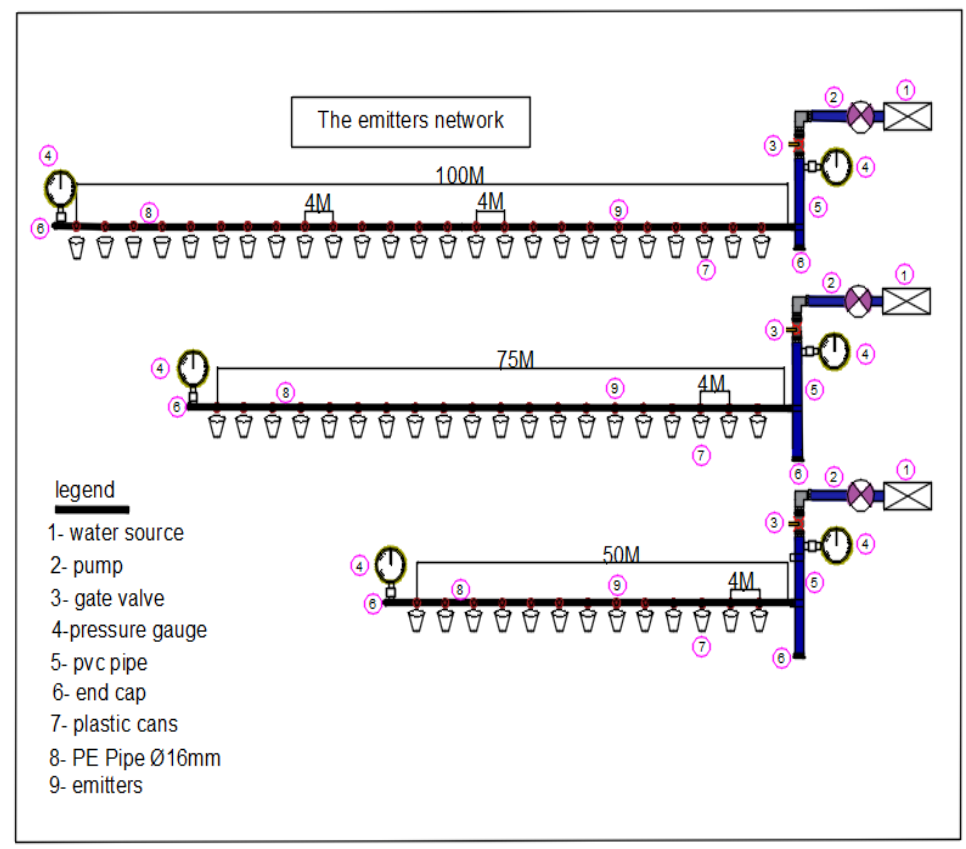

Fig. 2. The emitters network design in lab experiment.

\section{2- Field experiment}

Field experiment was conducted in July 2017 (private farm) in Wadi EL Natroon in Alex-CairoEgypt road.

A randomized field study was conducted on the farms, used the three emitters (OT2, KF and OT1) under lateral length $(50 \mathrm{~m})$ and emitter spacing (4 $\mathrm{m})$. The purpose of the field test was to determine the degree of clogging throughout the installation period and after 2 and 4 years. A field used the three emitters (OT2, KF and OT1) has been found for two months and has been used again for two years when farming in the farm was expanded and used four years ago by expanding the farm. Field experiments were carried out in one of the private farms of Wadi El Natroon, Egypt. The (OT2, KF and OT1) emitters in the field experiment using a length of 50 meters to determine the emitter clogging ratio in the field. When started the experiment, the cultivated area was about 200 feddans divided into: - Small area is $(225 \mathrm{~m} * 180 \mathrm{~m})$, Each of the small area contains a 2 -inch valve, a PVC pipe of $63 \mathrm{~mm}$ diameter derived from the main line to feed the manifold lines, and $16 \mathrm{~mm}$ Polyethylene pipes with (OT2, KF and OT1) emitters at distances of 4 meters between the emitters and 5 meters between the lines as shown in (Fig. 3). The irrigation process was carried out through the wells of the well with discharge of $100 \mathrm{~m}^{3} / \mathrm{h}$ in the presence of a screen filter station (6 inch). The irrigation system consists of the following components:

a) Pumping unit

Classification of pumping unit are presented in Table (3)

Table 3. Pump characteristics

\begin{tabular}{|c|c|}
\hline Pump type & characteristics type \\
\hline Speed & $2950 \mathrm{rpm}-50 \mathrm{HZ}$ \\
Head & $6 \mathrm{bar}$ \\
Flow rate & $120 \mathrm{~m}^{3} / \mathrm{h}$ \\
Voltage & $(380-680 \mathrm{~V})$ \\
Power & $22 \mathrm{KW}$ \\
\hline
\end{tabular}

\section{b) Mainline}

A PVC pipe of $160 \mathrm{~mm}$ diameter connects the control unit for conveying the water to sub-main lines. 


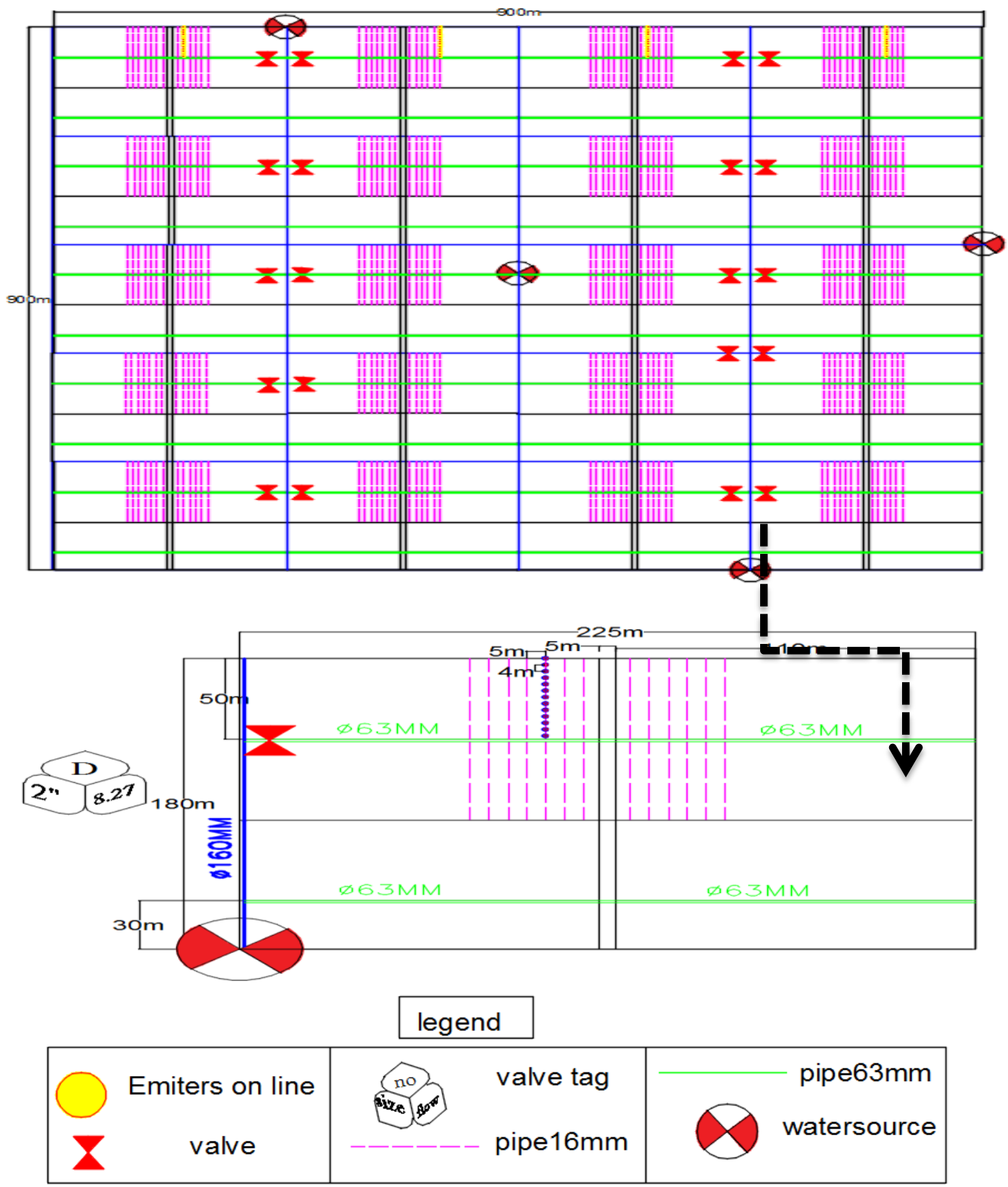

Fig. 3. Trickle irrigation network design and layout.

c) Sub-main lines

A PVC pipe of $63 \mathrm{~mm}$ diameter derived from the main line to feed the manifold lines.

\section{d) Lateral lines}

A PE pipe of $16 \mathrm{~mm}$ diameter connects to the sub-main lines to feed the emitters.

\section{e) Emitters}

Three type emitters (OT2, KF and OT1) were used in this experiment.

Performance and evaluation of the selected emitters

Some experiments were measured at laboratory using the hydraulic test bench that had been 
illustrated and tested for the emitter specifications according to ASAE 1996 b.

Emitter flow rate as a function of pressure can be expressed as follows according to Keller and Karmeli (1974);

$\mathbf{q}=\mathbf{k} \mathbf{P}^{\mathrm{x}}$

Where,

q emitter flow rate, $\mathrm{l} / \mathrm{h}$

$\mathrm{k}$ the constant of proportional that characterized each emitter

$\mathrm{p}$ Pressure at the emitter, bar

$x$ the emitter flow rate exponent, that characterized the flow regime

The manufacture's coefficient of variation "CV"

The manufacture's coefficient of variation "CV" is defined as the ratio of standard deviations of the discharges (Madramootto, 1988). The emitter manufacture's coefficient was calculated by measuring the flow rate from a sample of the new emitter:

$$
C V=\frac{s}{q_{a}} \times 100
$$

Where,

cv Manufacturer's coefficient of emitter variation.

s Standard deviation of emitter flow rates at a reference pressure head.

$\boldsymbol{q}_{\boldsymbol{a}}$ Mean flow rate of emitter at that reference pressure head. $(\mathrm{l} / \mathrm{h})$

\section{Flow variation}

This test was conducted at a water temperature of $(20-23)^{\circ} \mathrm{C}$. The pressure influence on emitter flow rate can be presented in two ways, either directly as the average of emitter flow rate or as a percentage of flow rate change that occurs at the actual operating pressure and pressure of 1 bar with the same water temperature, divided by the flow rate at pressure of 1 bar according to AEnRI and MSAE, 2002 as follows:

$$
q_{\mathrm{var}}=\left(\frac{q_{m}-q_{n}}{q_{n}}\right) 100
$$

Where:

$\mathrm{q}_{\mathrm{var}}=$ Variation of the average flow rate from the nominal one, (\%),

$\mathrm{q}_{\mathrm{m}}=$ Average flow rate, $(\mathrm{l} / \mathrm{h})$, and

$q_{n}=$ Nominal flow rate at pressure of 1 bar and the same water temperature, $(\mathrm{l} / \mathrm{h})$.

\section{Emission uniformity (EU)}

(ASABE, 2008R) revealed that the Emission uniformity (EU\%) used in trickle irrigation, while it is applied to sprinkler irrigation under the name of pattern efficiency is calculated according to the following equation:

$$
E U=\left[1-\frac{1.27 c v}{\sqrt{\mathrm{N}_{\mathrm{p}}}}\right] \times\left(\frac{q_{n}}{q_{a}}\right) \times 100
$$

Where

$\mathrm{Eu}=$ The emission uniformity, \%,

$\mathrm{CV}=$ Manufacturer's coefficient of emitter variation.

$\mathrm{q}_{\mathrm{n}}=$ The average of the lowest $1 / 4$ of the emitter flow rate, $\mathrm{l} / \mathrm{h}$, and

$\mathrm{q}_{\mathrm{a}}=$ The average of all Emitters flow rates, $\mathrm{l} / \mathrm{h}$.

$N_{p}=$ The Number of emitters per plant.

\section{Emitters clogging ratios}

To estimate the emitters flow rate cans and a stopwatch was used. Six emitters from each lateral had been chosen to be evaluated by calculating their clogging ratio at the beginning and at the end of the growing season. Clogging ratio was calculated after (EL-Berry et al 2003) using the following equations:

$$
\begin{aligned}
& E=\frac{q_{u}}{q_{n}} \times 100 . \\
& C R=(1-E) 100
\end{aligned}
$$

Where:

$$
\begin{aligned}
& \mathrm{E}=\text { the emitter flow rate efficiency }(\%) \\
& \mathrm{q}_{\mathrm{u}}=\text { emitter flow rate, at the end of the growing } \\
& \text { season (l/h) } \\
& \mathrm{q}_{\mathrm{n}}=\text { emitter flow rate, at the beginning of the } \\
& \text { growing season }(\mathrm{l} / \mathrm{h}) \\
& \mathrm{CR}=\text { the emitter clogging ratio (\%) }
\end{aligned}
$$

\section{Calculating consumption of power result used Emitters}

Horsepower is a measurement of the amount of energy necessary to do work. In determining the horsepower used to pump water, we must know the:

The theoretical power needed for pumping water is called water horsepower (whp),

(Guy Fipps, 2005) and is calculated by:

$$
\begin{aligned}
\text { whp } & =\frac{Q_{\mathrm{m}}(\mathrm{gpm}) \mathrm{xDH}(\mathrm{ft})}{3,960} \ldots \ldots \ldots \ldots \ldots(7) \\
\mathbf{b h p} & =\frac{w h p}{(\text { pumping plant efficiency })} \ldots \ldots \ldots(8)
\end{aligned}
$$


Where:

$Q_{\mathrm{m}}=$ pumping rate in gallons per minute (gpm), and

TDH = total dynamic head (TDH) in feet.

whp $=$ water horsepower

bhp $=$ brake horsepower

\section{RESULTS AND DISCUSSION}

\section{1- Laboratory experiment}

\section{1-1 The first part of laboratory experiment}

Effect of the operating pressure on the emitter flow rate for each emitter type was shown in Fig. (4). The experimental results of emitter flow pressure functions as well as the regression equation for the 16 emitters. Average flow rate as a function of operating pressure was determined for all emitter types. All correlation coefficient was above or equal (0.9) except (NC1, NPC1, RD, EN and $N N$ ) emitters, also they have very small flow rate exponent $(x)$ which indicates that there is a very small or negligible effect of the operating pressure on the flow rate of PC emitter. Almost all emitters were pressure compensating characteristics except (OT1, MPT, NC2, TKY and NC1) were turbulent flow regime while, NN and OT2 were partially pressure compensating. The influence of pressure can be presented as variable in two ways: either, directly as the average of emitter flow rate, or as variable percentage of flow rate variation related to the flow rate, the number of emitters studied were (16 emitters), divided into 9 imported emitters (KF, RD, EN, NN and CKF), were pressure compensating emitters while, (OT1, OT2, TKY and OT3) were non-pressure compensating emitters, and 7 local emitters (NPC1 and NPC2) were pressure compensating emitters and (NC1, NC2, NC3, NC4 and MPT) were non-pressure compensating emitters.

Performance curves of the manufacture's coefficient of variation (CV\%) for emitter

Emitter flow rate equation and manufacture's coefficient of variation "CV\%" for each emitter were determined and the result is shown in Fig. (5). The manufacture coefficient of variation "CV\%" is a function of the emitter type and the quality control exercised during the manufacturing process. The manufacture's coefficients of variation "CV\%" of different emitter types were relatively insensitive to the operating pressure and its classification varied from poor to excellent. Values of "CV\%" for the 16 emitter types varied between $3.37 \%$ to $24.77 \%$, depending on emitter's design, the material used, and care with which the emitter were manufactured, results showed that the Manufacture's coefficient of variation (CV\%) of all the emitters were excellent Except (NC2 and NPC1) emitter was average, (RD and NN) was poor, (EN) was unacceptable for emitter when operating pressure at 1 bar on beginning lateral line . by comparing 16 emitters under study in terms of the single flow rate of the imported and local emitters, the results indicate the lowest emitters in terms of the hydraulic performance of the manufacture's coefficient of variation (CV \%) was for the emitters (OT1, OT2, OT3, CKF, KF, TKY).

Performance curves of the emitter flow variation $\left(q_{v a r} \%\right)$ for emitter

Fig. (6) showed that, emitter flow variation $\left(q_{v a r} \%\right)$ for emitters at operating pressure of 1 bar. The values of emitter flow variation $\left(\boldsymbol{q}_{\boldsymbol{v} a r} \%\right)$ was between $12.45 \%$ to $20 \%$ (acceptable) and from $22.89 \%$ to $60.10 \%$ (unacceptable). Results showed that the emitter flow variation $\left(\boldsymbol{q}_{\text {var }} \%\right)$ of all the emitters were acceptable except (RD, EN, NPC1, and NN) emitter was Unacceptable for emitter when operating pressure at 1 bar on beginning lateral line. By comparing 16 emitters under study in terms of the single flow rate of the imported and local emitters, the results indicate that the lowest emitters in terms of the hydraulic performance of the emitter flow variation $\left(\boldsymbol{q}_{\text {var }} \%\right)$. were for the emitters (OT1, OT2, OT3, CKF, KF and TKY).

\section{Performance curves of the Emission uniformity (EU) \% for emitter}

EU values, for each emitter were determined and results as shown in Fig. (7), for the acceptable emitter types ranged from 80.92 to $95.83 \%$, which varied due to the variation of emitter manufacture. Results showed that, the Emission uniformity (EU\%) of all the emitter was excellent except (RD, EN and NN) emitter was good for emitter when operating pressure at 1 bar on beginning lateral line, by comparing 16 emitters under study in terms of the single flow rate of the imported and local emitters, the results indicate that, the highest emitters in terms of the hydraulic performance of the emission uniformity (EU\%), was for the emitters (OT1, OT2, OT3, CKF, KF and TKY). 


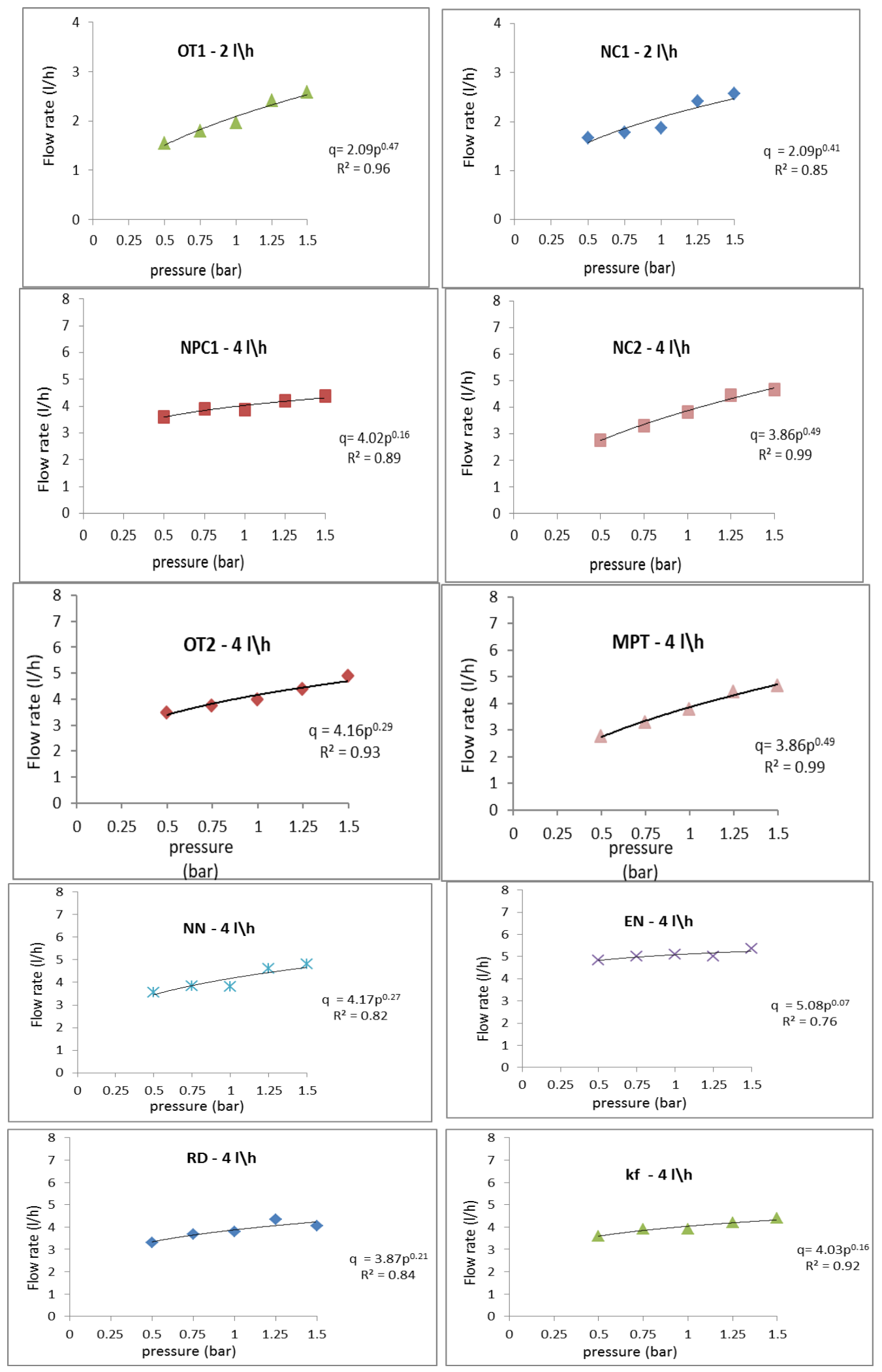



hydraulic performance
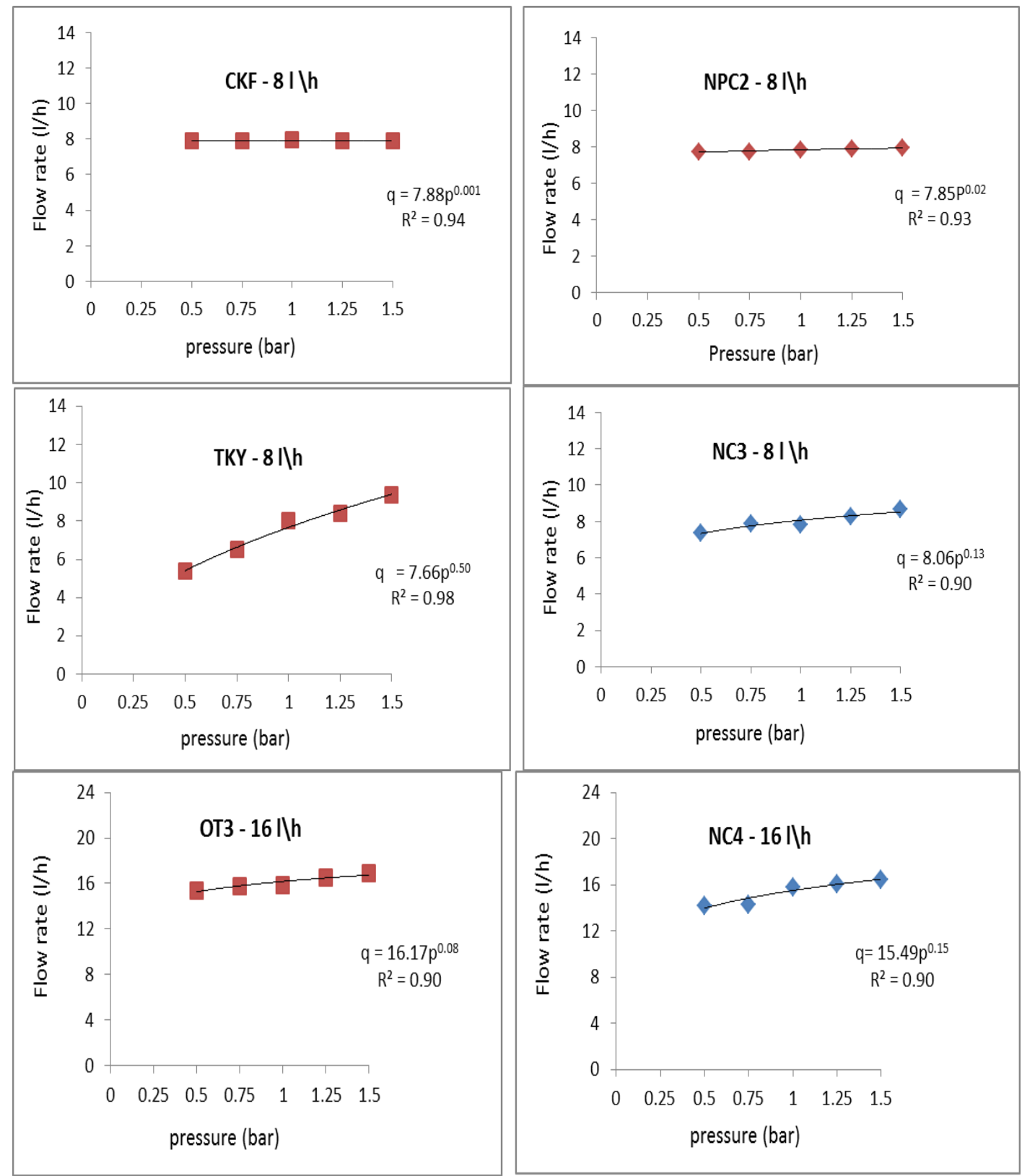

Fig. 4. Performance curves of the flow rates at different pressure along lateral line. 


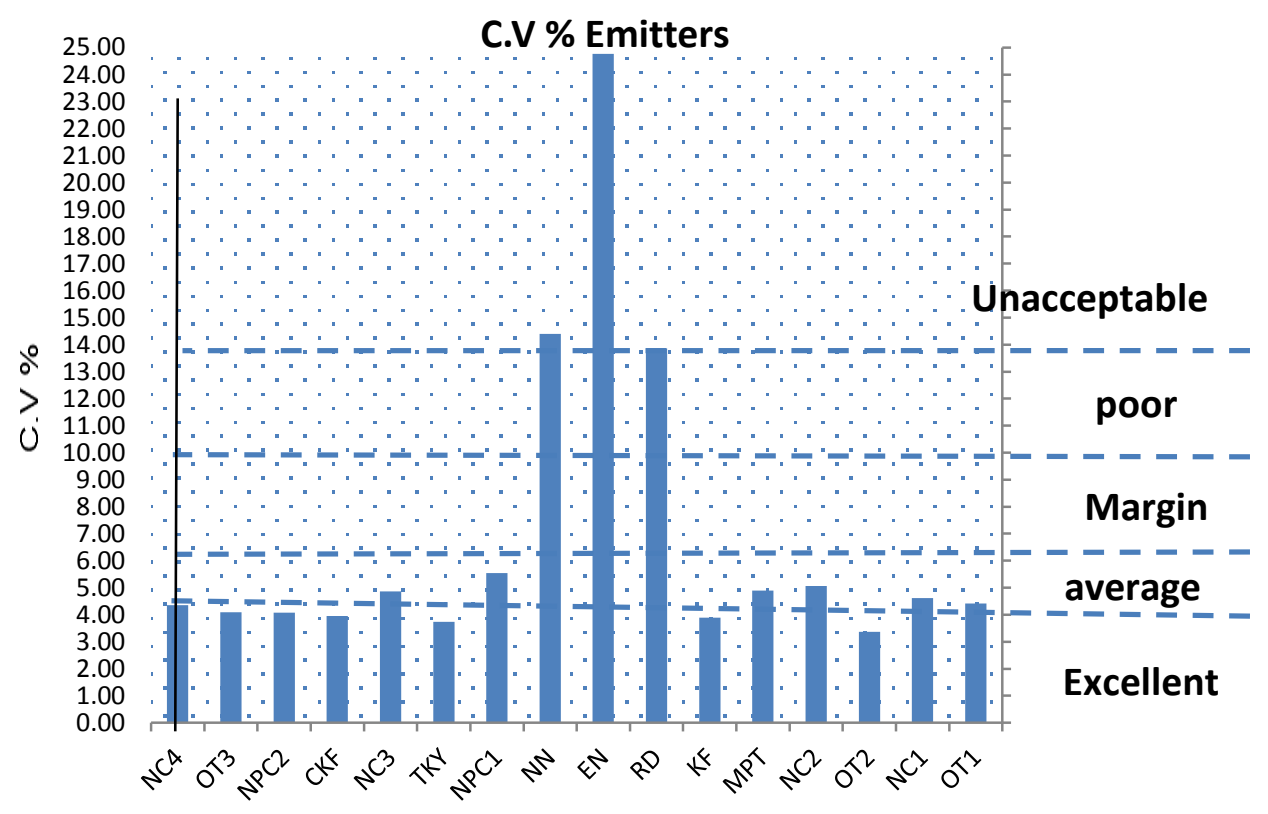

Fig. 5. Manufacture's coefficient of variation (CV \%) at different emitters.

$$
\text { ( } \left.q_{\text {var }} \%\right) \text { Emitters }
$$

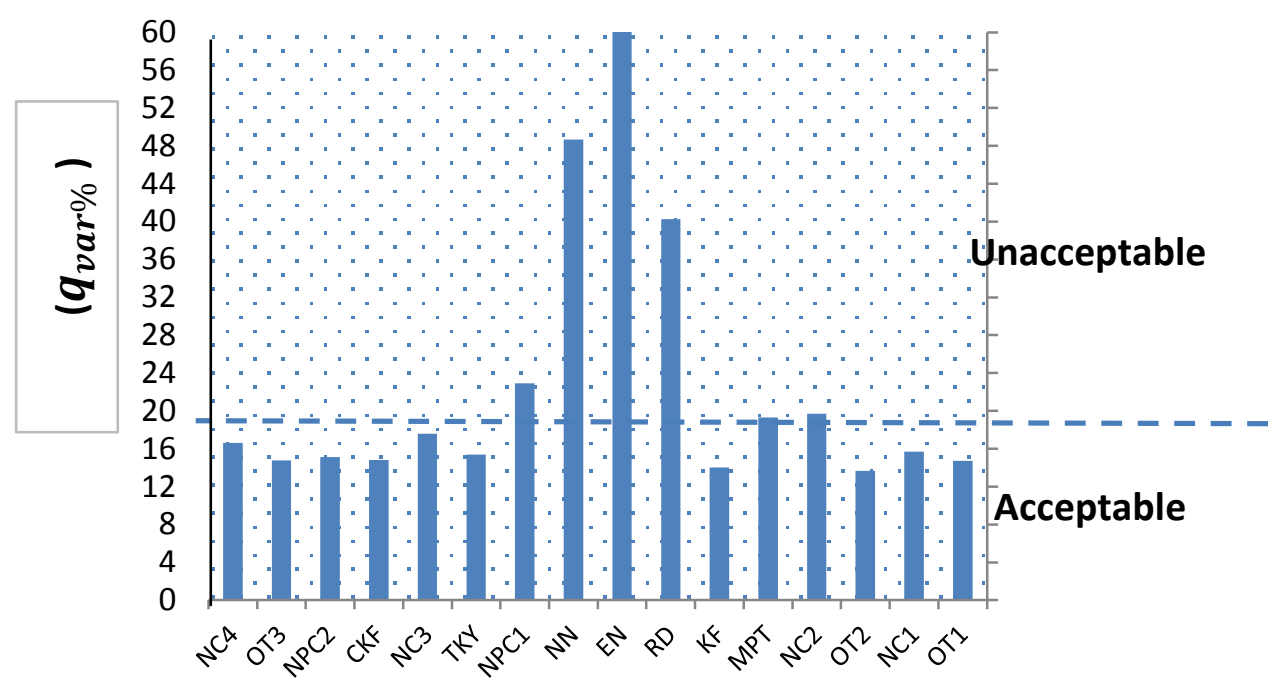

Fig. 6. Emitter flow variation $\left(q_{v a r} \%\right)$ rate. 


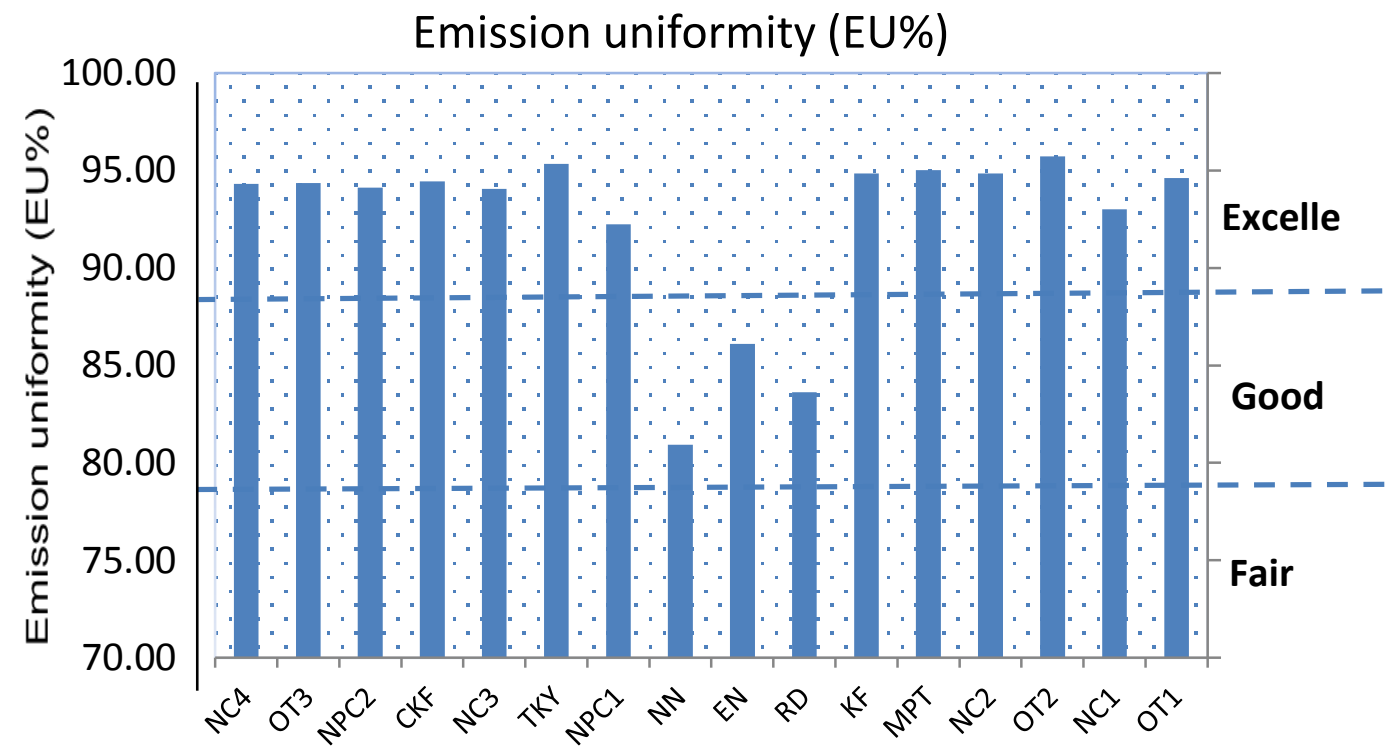

Fig. 7. Emission uniformity (EU \%) at different emitters.

\section{1-2. The second part of laboratory experiment}

\section{Emission uniformity (EU \%)}

Table (4) showed that the effect of lateral length on emission uniformity (EU\%) for different emitters tested effect of 6 emitter (OT1, OT2, KF, TKY, CKF and OT3). discharges of emitters were (2) $\mathrm{L} / \mathrm{h}$ non- pressure compensating (NPC) $4 \mathrm{I} / \mathrm{h}$ non- Pressure compensating (NPC), $4 \mathrm{l} / \mathrm{h}$ pressure compensating (PC), 8 I / h non- pressure compensating (NPC), $8 \mathrm{I} / \mathrm{h}$ pressure compensating $(\mathrm{PC})$ and $16 \mathrm{I} / \mathrm{h}$ non- Pressure compensating (NPC) respectively, under different lateral length (50 m, $75 \mathrm{~m}$ and $100 \mathrm{~m}$ ) for emitter spacing $4 \mathrm{~m}$ between emitters. Results showed that the highest value of emission uniformity was $(96.67 \%)$ for (OT2) emitter under lateral length of $50 \mathrm{~m}$ for emitter spacing ( 4 meter) while the lowest value was $(84.84 \%)$ under lateral length of $100 \mathrm{~m}$ for (OT3) In general, as expected, the results indicate that EU increased with decreasing lateral length from $100 \mathrm{~m}$ to $50 \mathrm{~m}$ in case non- Pressure compensating emitters (OT1, OT2, TKY and OT3) and in case Pressure compensating emitters, (KF and CKF), the results showed that the uniformity is for emitter (KF) at $100 \mathrm{~m}$ equal $96.32 \%$ and for emitter (CKF) at $100 \mathrm{~m}$ equal $96.08 \%$, due to the fact that the emitters flow rate exponent $(x)$ for emitter is near zero.

Table 4. Emission uniformity (EU \%) for type of emitters under different lateral lengths at emitter spacing of $4 \mathrm{~m}$

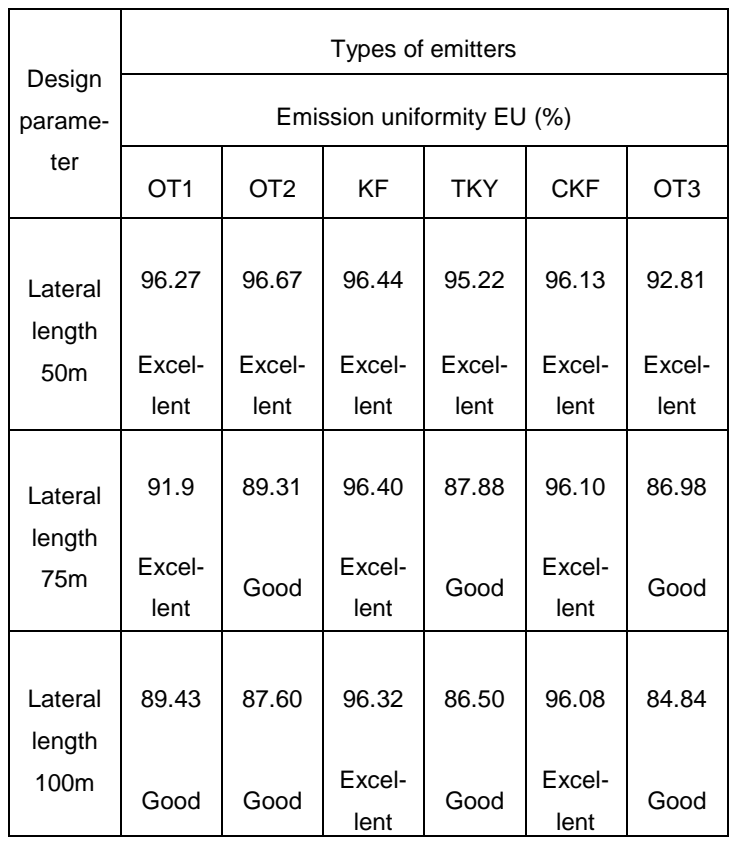




\section{Friction losses $\left(\mathbf{h}_{\mathbf{f}}\right)$}

Table (5) showed that the effect of lateral length on friction losses $\left(\mathrm{h}_{\mathrm{f}}\right)$ under different lateral length for emitter spacing $4 \mathrm{~m}$ was tested effect of 6 emitter (OT1, OT2, KF ,TKY, CKF and OT3), (2) $\mathrm{L} / \mathrm{h}$ non- Pressure compensating (NPC), $4 \mathrm{I} / \mathrm{h}$ non- Pressure compensating (NPC) , $4 \mathrm{I} / \mathrm{h}$ Pressure compensating (PC) , $8 \mathrm{I} / \mathrm{h}$ non- Pressure compensating (NPC), 8 I / h Pressure compensating (PC), $16 \mathrm{I} / \mathrm{h}$ non- Pressure compensating (NPC) respectively. The results showed that the lowest value of friction losses was $(0.02 \mathrm{~m})$ for (OT2) emitter under lateral length of $50 \mathrm{~m}$ for emitter spacing (4 meter) while the highest value was $(3.75 \mathrm{~m})$ under lateral length of $100 \mathrm{~m}$ for (OT3) the results indicate that friction losses increased with increasing lateral length from $50 \mathrm{~m}$ to $100 \mathrm{~m}$ and emitters number increased across the lateral length, friction losses also increased due to emitters inlet and outlet resistances coefficient of variation (CV\%), in case non- Pressure compensating emitters but different in case Pressure compensating emitters since the amount of loss in friction with the length of the line does not affect the flow of the emitters at the end of the line.

Table 5. Friction losses $\left(h_{f}\right)$ under different lateral lengths at spacing emitter $4 \mathrm{~m}$

\begin{tabular}{|ccccccc|}
\hline \multicolumn{7}{|c|}{ Actual friction losses $\mathbf{( m )}$} \\
\hline \multicolumn{7}{c|}{ emitters } \\
\hline $\begin{array}{c}\text { Lateral } \\
\text { lengths }\end{array}$ & OT1 & OT2 & KF & TKY & CKF & OT3 \\
\hline $\mathbf{5 0 m}$ & 0.05 & 0.02 & 0.03 & 0.23 & 0.12 & 0.77 \\
\hline $\mathbf{7 5 m}$ & 0.09 & 0.21 & 0.10 & 0.42 & 0.29 & 2.11 \\
\hline $\mathbf{1 0 0 m}$ & 0.15 & 0.35 & 0.25 & 1.50 & 0.75 & 3.75 \\
\hline
\end{tabular}

The effect of emitters type and lateral length on consumption of power, for 6 emitters

Fig. (8) showed that consumption of power values for 6 emitters under different parameters such as lateral length $(50,75$ and $100 \mathrm{~m})$ at the spacing between emitter of $4 \mathrm{~m}$. The data showed that the consumption of power was $(0.004,0.01$, $0.01,0.02,0.02$ and $0.04 \mathrm{hP}$ ) for 6 emitters (OT1, OT2, KF, TKY, CKF and OT3) respectively, for the lateral length $50 \mathrm{~m}$, and was $(0.01,0.01,0.01,0.03$, 0.02 and $0.08 \mathrm{hP}$ ) for the lateral length $75 \mathrm{~m}$, and was $(0.01,0.02,0.02,0.04,0.04$ and $0.14 \mathrm{HP})$, for the lateral length $100 \mathrm{~m}$. The results showed that the lowest consumption of power were $0.004 \mathrm{HP}$ at $50 \mathrm{~m}$ lateral length, as expected, the results indi- cate that consumption of power increased with increasing lateral length from $50 \mathrm{~m}$ to $100 \mathrm{~m}$ and emitters number increased across the lateral length, The figure shows that when using the emitters (KF and CKF), the lowest power consumption is given due to the ratio of (cv) of the emitter and its Regular internal paths.

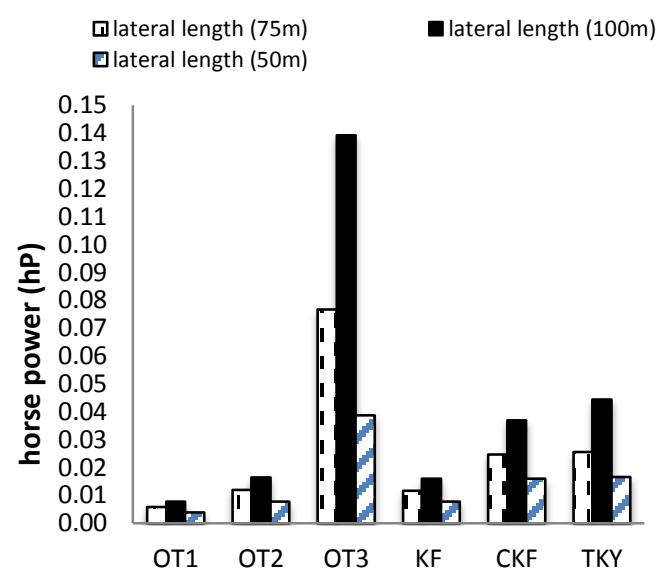

Fig. 8. The effect of type of emitters and lateral length on consumption of power, for 6 emitters.

Evaluating of the best 6 emitters under this study, depend on (EU \%, price), at different lateral length

The results showed that the best conditions for operation the emitters were at $50 \mathrm{~m}$ lateral length for 6 emitters, and therefore compared the six emitters in terms of prices and emission uniformity (EU\%), Fig. (9) showed that emitter of the (CKF) was high price and high emission uniformity (EU\%), emitter of the (TKY) was high price and low emission uniformity (EU \%), emitter of the (OT3) was low price and low emission uniformity (EU \%), emitters of the (OT2, KF and OT1) were low price and high emission uniformity (EU \%). The results showed that the best results were at $50 \mathrm{~m}$ lateral length for emitters (OT2, KF and OT1), ( 4 I/h Non Pressure compensating, 4l/h Pressure compensating, $2 \mathrm{l} / \mathrm{h}$ Non Pressure compensating ) respectively, were the lowest price and the highest emission uniformity (EU \%). From the last result in laboratory, we realized that emitter (OT2) was the highest emitter on emission uniformity (EU \%) and was the lowest actual friction losses under lateral length $(50 \mathrm{~m})$ and emitter spacing $(4 \mathrm{~m})$. By comparing prices with emission uniformity (EU\%), the emitter (OT2) was the lowest price and the highest emission uniformity (EU\%). 


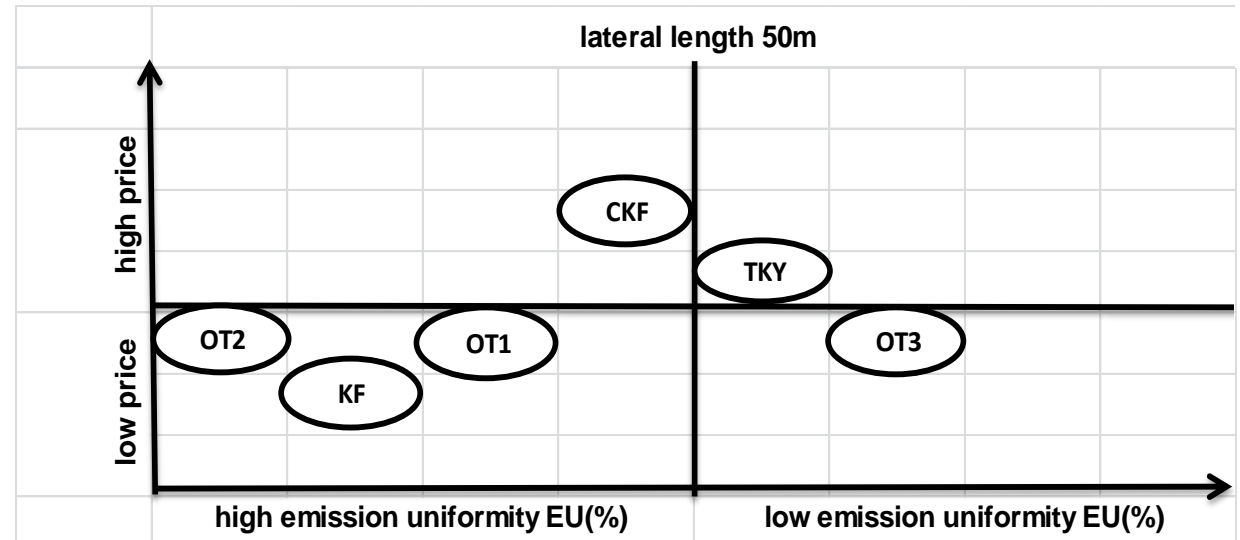

Fig. 9. A relationship between the emission uniformity (EU \%) and price of six emitters at lateral length $50 \mathrm{~m}$.

\section{Field experiment}

\section{The emitter (OT2) clogging ratio}

From the last result in laboratory and through evaluation the 6 emitters under study in terms of prices and Emission uniformity (EU\%), a randomized field study was conducted on the farms where the three emitters (OT2, KF and OT1) under lateral length $(50 \mathrm{~m})$ and emitter spacing $(4 \mathrm{~m})$. The purpose of the field test was to test the degree of clogging throughout the installation period. A field used an emitter (OT2, KF and OT1) have been found for two months and has been used again for two years when farming in the farm was expanded and used four years ago by expanding the farm. Table (5) showed that the emitter (OT2) clogging ratio was $3.09 \%$ within two months was $6.95 \%$ within two years and $10.49 \%$ within 4 years. The results showed that the lowest degree of 5 clogging ratio of the emitter (OT2) was within two months of operation. In general, and as expected, the results indicate that clogging ratio increased with increasing the time of installation of the field emitter and the range of factors affecting the periodic maintenance and design of good and components of irrigation network with high quality.

Table 5. The degree of clogging for on line emitter over time:

\begin{tabular}{|c|c|c|c|}
\hline The duration of & \multicolumn{3}{|c|}{ clogging ratio, \% } \\
\cline { 2 - 4 } the emitters in & \multicolumn{3}{|c|}{ Emitter Name } \\
\cline { 2 - 4 } the field & OT2 & OT1 & KF \\
\hline 2 months & 3.09 & 5.26 & 683 \\
2 years & 6.95 & 11.11 & 13.63 \\
4 years & 10.49 & 17.64 & 20.96 \\
\hline
\end{tabular}

\section{CONCLUSION}

This study was conducted to evaluate the performance of some local and imported emitters for improving their hydraulic performance. The results of this study can be summarized in the following points:

1. By Comparing (16 emitters) the hydraulic performance of some emitters including manufacture's coefficient of variation (CV\%), emitter flow variation $\left(q_{\mathrm{var}} \%\right)$ and the Emission uniformity (EU \%). The results showed 6 of the best emitters were (OT1, OT2, KF, TKY, CKF and OT3), (2) L / h non-pressure compensating (NPC), $4 \mathrm{l} / \mathrm{h}$ non-pressure compensating (NPC), $4 \mathrm{l} / \mathrm{h}$ pressure compensating (PC), $8 \mathrm{l} / \mathrm{h}$ non-pressure compensating (NPC), $8 \mathrm{l} / \mathrm{h}$ Pressure compensating (PC) and $16 \mathrm{I} / \mathrm{h}$ nonPressure compensating (NPC), respectively.

2. Were using 6 emitters in the second part of the laboratory experiment to evaluate the side lines under the length of the PE tube (50 - 75 - 100 $\mathrm{m})$ at a distance between the emitters $(4 \mathrm{~m})$ for the calculation of the Emission uniformity (EU $\%)$ and the coefficient of friction of the hydraulic. The results showed the best emitter was (OT2) was the Emission uniformity was $(96.67 \%)$ and the coefficient of friction of the hydraulic was $(0.02 \mathrm{~m})$.

3. From the last result in laboratory realized that emitter (OT2) is the best emitter on emission uniformity (EU\%) and Actual friction losses under different lateral length $(50 \mathrm{M})$ for emitter Spacing (4 M) for on line emitter, so was chosen to test it in the field. A questionnaire was conducted on the use of emitter (OT2) in a variety of fields. A special field using emitter 
(OT2) has been selected for years. The emitter (OT2) was tested in the field to see the degree of clogging after four years and two years and after two months and the impact of the clogging of the emitter on irrigation network. The result showed that the lowest degree of Clogging of the emitter (OT2) was within two months of operation was $(3.09 \%)$ while the highest was $(20.96 \%)$ degree of Clogging of the emitter (KF) was within 4 years of operation).

\section{REFERENCES}

Abdelsalam, H.S. 2016. Effect of Some Engineering Factors On Pressurised Irrigation Performance. M.SC. Benha Univ., Benha, Egypt, pp. 13-16.

Ayars, J.E., Phene, C.J., Hutmacher, R.B., Davis, K.R., Schoneman, R.A., Vail, S.S. and Mead, R.M. 1999. Subsurface drip irrigation of row crops: A Review of 15 Years of Research at the Water Management Research Laboratory. Agric. Water Manage. 42, 1-27. Bachelor, C.H., Lovell, C.J., Murata, M. Simple micro irrigation techniques for improving irrigation efficiency on vegetable gardens. Agric. Water

Evans R.G. 2000. Irrigation Techniques. USDAARS-NPARL, Sidney, Montana 59270406 433 2020, pp. 12-14.

Hamman D.Z. and Izno F.T. 1989. Principle of Micro Irrigation, Fact Sheet AE-24, University of Florida, USA. pp. 19-20.

Hillel D., 1987. The effect use of water in irrigation; Principles, practices for improving irrigation in Arid and Simiarid Regions. World Bank Technical Paper No. 64. The World Bank, Washington D.C, USA.
Kimura L. 1987. Emitter hydraulic and their role in obtaining high emission uniformity design. In: Micro- irrigation methods. J. Agri. Eng. Res., 32,102-106.

Madramotto, C.A. 1988. Effect of pressure changes characteristics on the discharge characteristics of pressure compensating emitters. J. Agri. Eng. Res., 40, 159-164.

Özekici, B., and Sneed R.E. 1995. Manufacturing variation for various trickle irrigation on-line emitters. Appl. Eng. Agric. St. Joseph. MI: ASAE, 1985-Mar., 2, 235-240.

Phocaides A. 2000. Technical Hand Book on Pressurized Irrigation Techniques. FAO Consult., Rome, Italy, 195p.

Postel, S. 1999. Pillar of Sand: Can the Irrigation Miracle Last? W.W. Norton \&Company, New York, USA. 313 p.

Ribeiro, P.A.A. and Coelho, R.D. 2010. Teixeira, M. B. Entupimento de tubos gotejadores convencionais com aplicação de cloreto de potássio (Branco e vermelho) via duas qualidades de água. Engenharia Agrícola, 30, 279-287.

Sinobas L.R. and Rodríguez M.G. 2012. A Review of Subsurface Drip Irrigation and It Management, Water Quality, Soil and Managing Irrigation of Crops, Dr. Teang Shui Lee (Ed.), ISBN, 978-953- 51-0426-1.

Tagar A.A., Mirjat M.S., Soomro A. and Sarki A. 2010. Hydraulic performance of different emitters under varying lateral lengths. Pak. J. Agri., Agril. Engg., Vet. Sci., 26 (2), 48-59 .

Tripathi, V.K., Rajput, T.B.S. and Patel, N., Lata, 2011. Hydraulic performance of drip irrigation system with municipal wastewater. J. Agric. Eng. 48 (2), 15-22. 
المؤتمر الرابع عشر لبحوث التنمية الزراعية،

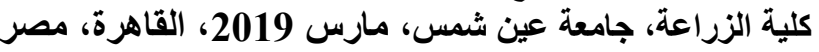

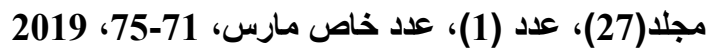

Website: http://strategy-plan.asu.edu.eg/AUJASCI/

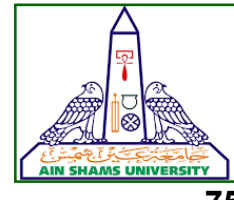

تقييم أداء بعض المنقطات المحلية والمستوردة لتحسين أدائها الهيدروليكي.

أسماء أحمد محمود محمد1'- أحمد ابو الحسن عبد العزيز ${ }^{1}$ أسامة محمد احمد بدير

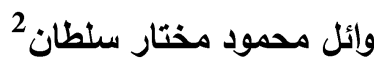

1. قسم الهنسة الزراعية- كلية الزراعة- جامعة عين شمس- ص.ب 68- حدائق شبرا 11241- القاهرة- مصر

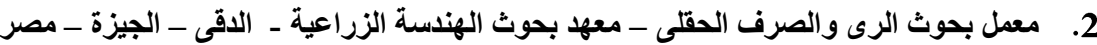

“Corresponding author: asmaa.1641991@gmail.com

Received 6 January, 2019,

Accepted 10 February, 2019

الخطوط الجانيية تحت اطوال خراطيم (50 - 75 - 75 - لئن

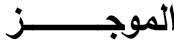

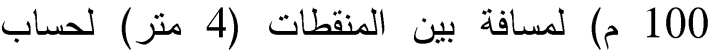

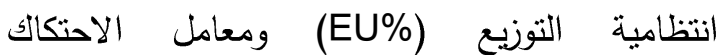

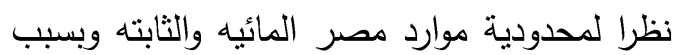

الهيدروليكي والقدرة المستهلكة نتنيجه لاستخدام

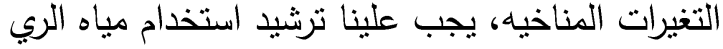

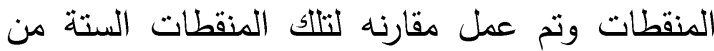

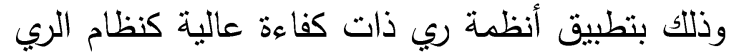

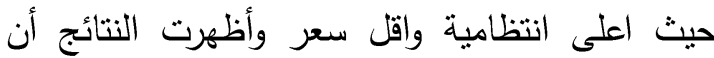

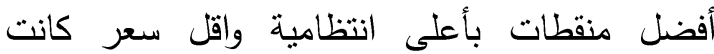

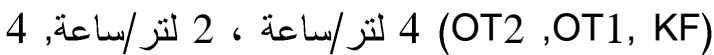
لتز/ساعة على التزتيب، وقد اجريت التجرية الحقليه

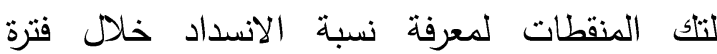

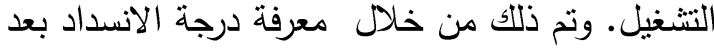

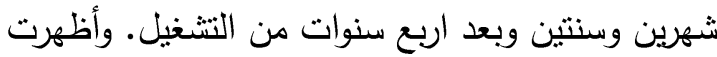

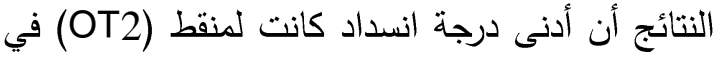

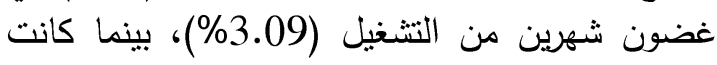
أعلى درجة (20.96\%) من انسداد الباعث (KF) خلال 4 سنوات من التشغيل). بالتتقيط، ومن المعروف ان الري بالتتقيط هو أحد طرق الترق

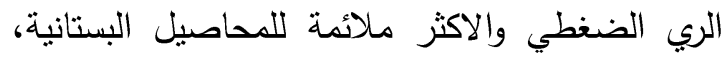

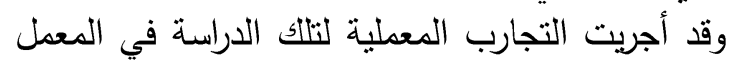

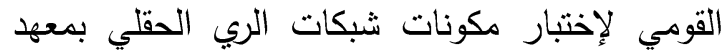

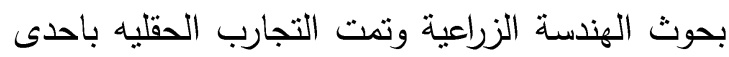

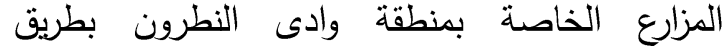

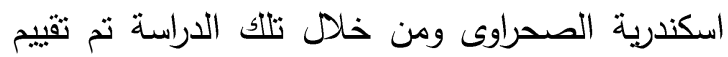

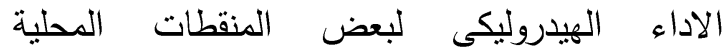

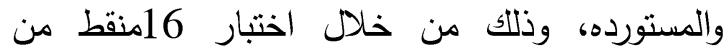

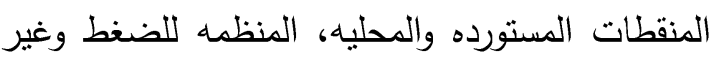

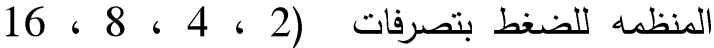
التز//ساعة)، وقد أظهرت النتائج ستة منقطات كانت الأفضل عند مقارنة معدل الاداء الهيدروليكى لكل منهم التهات

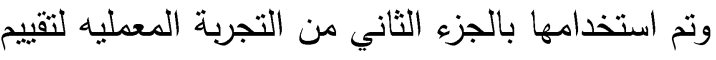

تحكيم: ا.د عبدالغني محمد الجندي

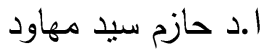

